\title{
Left atrial appendage closure in secondary prevention of stroke in a patient with atrial fibrillation as well as prior stroke and iatrogenic intracranial haemorrhage
}

Zamknięcie uszka lewego przedsionka w profilaktyce wtórnej udaru mózgu u pacjentki z migotaniem przedsionków oraz przebytym zawałem mózgu i jatrogennym krwawieniem wewnątrzmózgowym

\section{Anetta Lasek-Bal, Przemysław Puz}

Stroke Unit, Clinical Hospital no. 7, Medical University of Silesia, Upper Silesian Medical Centre, Katowice, Poland

Postep Kardiol Inter 2012; 8, 3 (29): 250-252 DOI: $10.5114 /$ pwki.2012.30406

\begin{abstract}
We present a case of a female patient after a transient ischaemic attack (TIA) and a brain infarction, in addition to other risk factors for stroke including atrial fibrillation, in whom warfarin was used for secondary prevention. Three months after a brain infarction, the patient experienced bleeding in the left hemisphere of the brain that was most likely a complication of anticoagulant therapy. Given the restrictions in the choice of stroke prevention methods, and the limitations associated with the patient's negativism, we decided to use an alternative method for secondary prevention of cerebral ischaemia, namely percutaneous closure of the left atrial appendage (LAA). The procedure and post-procedure course were uneventful. During an 8-month follow-up, the patient did not experience new cerebrovascular accidents.
\end{abstract}

Key words: left atrial appendage, stroke

\section{Streszczenie}

Przedstawiono chorą, u której po przejściowym ataku niedokrwiennym (ang. transient ischemic attack - TIA) oraz zawale mózgu, wobec obecnych czynników ryzyka niedokrwienia mózgu, w tym migotania przedsionków (ang. atrial fibrillation - AF), w profilaktyce wtórnej zastosowano warfarynę. Po 3 miesiącach od zawału mózgu wystąpiło krwawienie do lewej półkuli mózgu będące najpewniej powikłaniem stosowanej terapii antykoagulantem. Wobec ograniczeń w wyborze profilaktyki udaru mózgu oraz wynikających z negatywizmu pacjentki zdecydowano się na alternatywną metodę wtórnej profilaktyki niedokrwienia mózgu - przezskórne zamknięcie uszka lewego przedsionka (ang. left atrial appendage - LAA). Zabieg oraz okres pooperacyjny przebiegły bez powikłań. W 8-miesięcznej obserwacji nie stwierdzono u pacjentki świeżych incydentów naczyniowych mózgu.

Słowa kluczowe: uszko lewego przedsionka, udar mózgu

\section{Introduction}

Stroke accounts for about $90 \%$ of thromboembolic complications in atrial fibrillation (AF). It is believed that all types of AF (paroxysmal, persistent or permanent) are associated with comparable risk for brain infarction. It is estimated that among people $<60$ years of age, the incidence of atrial fibrillation is $0.1-0.2 \%$, while in patients older than 80 years it is $9.1-11 \%$ [1-3]. In patients with stroke, $\mathrm{AF}$ is present in $15-25 \%$ of cases, including $4 \%$ of patients under 55 years of age [4]. The so-called clinically silent brain infarctions (detected in neuroimaging studies) in atrial fibrillation are noteworthy, as they can be the underlying cause of cognitive disorders.

Anticoagulation is recommended for stroke prevention in patients with atrial fibrillation (class I, level A). In patients who are unable to use oral anticoagulants, antiplatelet therapy is recommended (class I, level A) [5]. Bleeding is an important complication of oral anticoagulant therapy, and

\section{Corresponding autor/Adres do korespondencji:}

Anetta Lasek-Bal, Stroke Unit, Clinical Hospital no. 7, Medical University of Silesia, Upper Silesian Medical Centre, 45/47 Ziołowa, 40-635 Katowice, Poland, tel.: +48 3235983 03, +48 502695 389, fax: +48 32202 95 92, e-mail: balanett@poczta.onet.pl

Praca wptynęła: 4.04.2012, przyjęta do druku: 18.07.2012. 
its incidence, according to different authors, is estimated at 7.6-9.4\% [6]. Left atrial appendage closure in patients with atrial fibrillation and reccurent brain ischaemia in spite of antithrombotic therapy, and/or in the case of iatrogenic bleeding, may be a therapeutic option in reduction of the risk for stroke and associated severe complications. The role of left atrial appendage occlusion as a treatment strategy for secondary prevention of stroke is currently undetermined, and the decision on its application should be preceded by a thorough analysis of indications and potential benefits for each patient, especially in the elderly.

\section{Case report}

A 74-year-old female patient with comorbidities, including hypertension, coronary artery disease, atrial fibrillation, diabetes, renal failure, TIA, using aspirin (at a dose of 100 $\mathrm{mg}$ ) was admitted to the hospital because of sudden onset of weakness left limbs. At admission, the physical examination revealed dysarthria and a left-sided hemiparesis with ataxia of the left limbs (8 points on the NIH Stroke Scale). A computed tomography (CT) of head scan showed signs of vascular brain injury. The patient was admitted to the Stroke Unit, where diagnostic procedures excluded the presence of haemodynamically significant carotid and cerebral artery stenoses, but many embolic signals in the middle cerebral arteries were detected.

For secondary prevention of stroke, warfarin was introduced with the use of the international normalized ratio (INR) to control warfarin therapy ( 5 points on the $\mathrm{CHA}_{2} \mathrm{DS}_{2}$ VASc Scale, 4 points on the HAS-BLED scale). The patient left the hospital in a good general condition (1 point on the Rankin Scale). In the second month after brain infarction, the patient underwent angioplasty with a stent implantation into the left anterior descending artery. Therapy with an oral anticoagulant was maintained. One month later, acute dysarthria and right legs weakness occurred. Neurological examination revealed severe mixed aphasia, central facial palsy, and a right-sided hemiparesis (10 points on the National Institutes of Health Stroke Scale (NIHSS)). A CT scan of head revealed intracerebral haemorrhage in the region of the internal capsule in the left hemisphere (Figure 1). The INR on the day of onset of symptoms was 1.7. The patient was admitted again to the Stroke Unit, where her condition improved. At discharge, only motor aphasia was present, which did not impair verbal communication significantly (1 point on the Rankin Scale).

Because of the need for anticoagulation, together with an increased risk of side effects of this therapy (7 points on the $\mathrm{CHA}_{2} \mathrm{DS}_{2}$ VASc Scale, 6 points on the HAS-BLED Scale), the patient was treated with percutaneous left atrial appendage closure. The procedure was performed in the Department of Invasive Cardiology, Upper Silesian Medical Centre in Katowice in the second month after intracranial haemorrhage (Figure 2). The patient is currently in an outpatient follow-up. The neurological examination in the eighth month after LAA closure revealed mild aphasia. The control ultrasound monitoring of the middle cerebral arteries demonstrated embolic signals. The patient uses aspirin in a daily dose of $100 \mathrm{mg}$.

\section{Discussion}

Atrial fibrillation is associated with a 5 -fold increase in the likelihood of ischaemic stroke, with the annual risk in

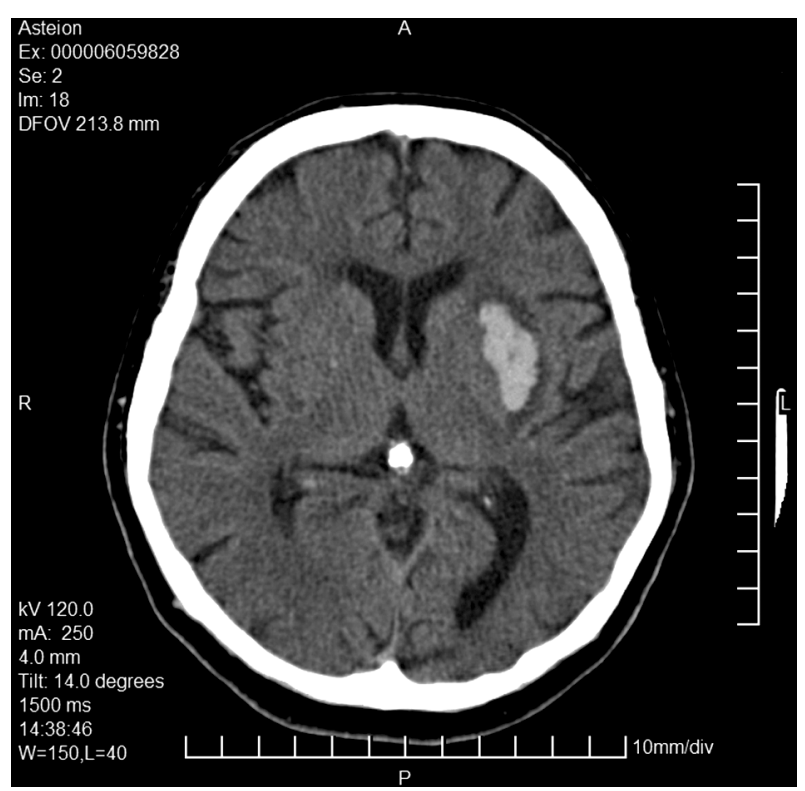

Fig. 1. Left hemisphere haemorrhage

Ryc. 1. Krwotok do lewej pótkuli mózgu

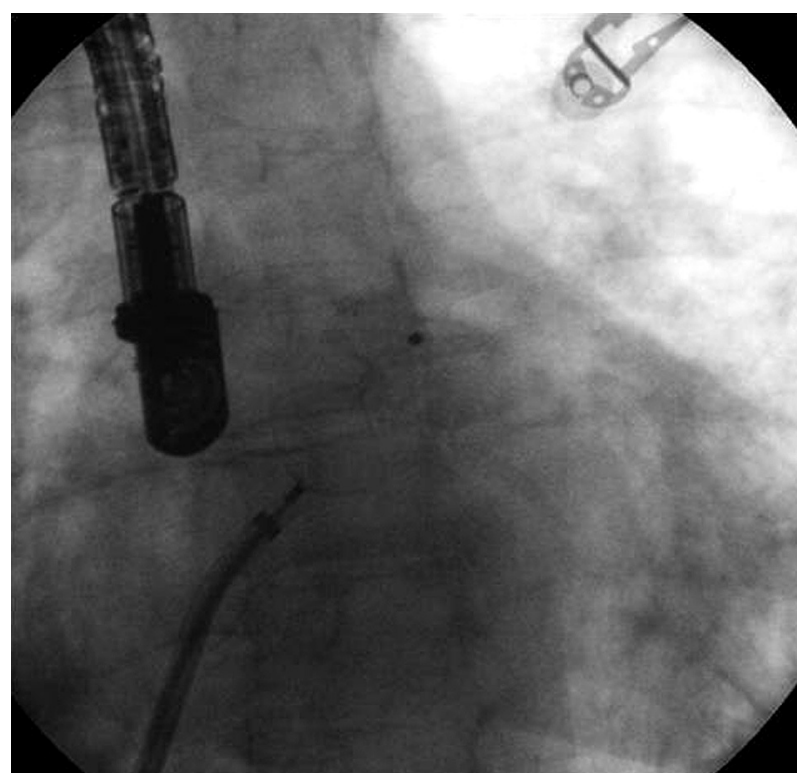

Fig. 2. Implantation of left atrial appendage device (Amplatzer Cardiac Plug)

Ryc. 2. Implantacja okludera uszka lewego przedsionka (Amplatzer Cardiac Plug). Zdjęcie dzięki uprzejmości dr. Przemystawa Węglarza 
these patients, according to different authors, varying from $2 \%$ to $10 \%$ [7]. The risk is high in patients $>75$ years of age, with concomitant hypertension, diabetes, structural heart disease, and in patients with a history of an ischaemic cerebral accident (for most of those diseases the risk increases by a quarter for each decade of life) [7]. For the risk assessment of vascular brain incident in patients with $A F$, the $C_{H A} \mathrm{DS}_{2}$ VASc Scale is used [it is a modification of the CHADS scale developed based on the results of the SPAF (Stroke Prevention in Atrial Fibrillation) trial]. The scale uses a scoring system. A total point score of at least 2 points means that a patient is in a group at high risk for cerebral ischaemia. This scale has a high accuracy in the assessment of patients' risk in 1-year and 10-year follow-up (respectively 0.85 and 0.88) [8]. Patients with a total point score of at least two points should receive anticoagulant therapy with the use of INR to control the therapy. The use of oral anticoagulants reduces the relative risk of ischaemic stroke, including a risk reduction by $67 \%$ with warfarin (recommended at high risk of ischaemic stroke), and with aspirin by $22 \%$ [9]. It is associated, however, with bleeding complications, including intracranial bleeding, with the incidence estimated at $0.2 \%$ per year [9]. The HAS-BLED Scale developed on the basis of the Euro Heart Survey allows for risk stratification of haemorrhage. A total point score of at least 3 points on this scale is associated with the threat of its occurrence. The incidence of intracranial bleeding is increased with INR $>3.5$, but no difference is observed at INR 2.0-3.0, compared with lower values [10].

It is believed that because of drug intolerance and/or bleeding complications up to $54 \%$ of patients at high risk of cardioembolic complications do not receive oral anticoagulants [11]. The introduction of inhibitors of factor II and factor Xa of the coagulation system gives the opportunity for effective protection of patients with non-valvular AF. Another alternative is the percutaneous closure of LAA, the most common site of thrombus formation in the heart. The results of the PROTECT-AF study demonstrated that the effectiveness of this method in the prevention of complications of AF is comparable to anticoagulation [12]. In a group of 5 patients, Kukuła et al. reported an uneventful periprocedural period and follow-up with a median length of 54 months [11].

Taking into account the risk for brain infarction and, at the same time, for iatrogenic bleeding in our patient, we decided to use an alternative method of stroke prevention: percutaneous left atrial appendage closure (LAA). After the cardiac intervention, in an 8-month neurological follow-up, there were neither incidents reflecting disorders in cerebral circulation, nor complications of the therapy.

Because patients in whom LAA closure is considered belong to a group of patients with many comorbidities, the correct qualification for the procedure and performing the procedure require close cooperation of a neurologist and a cardiologist with experience in this area.

\section{References}

1. Wolf PA, Abbott RD, Kannel WB. Atrial fibrillation as an independent risk factor for stroke: the Framingham Study. Stroke 1991; 22: 983-988.

2. Furberg CD, Psaty BM, Manolio T, et al. Prevalence of atrial fibrillation in elderly subjects (the Cardiovascular Health Study). Am J Cardiol 1994; 74: 236-241.

3. Go AS, Hylek EM, Phillips KA, et al. Prevalence of diagnosed atrial fibrillation in adults: national implications for rhythm management and stroke prevention: the AnTicoagulation and Risk Factors in Atrial Fibrillation (ATRIA) Study. JAMA 2001; 285: 2370-2375.

4. Putaala J, Metso AJ, Metso TM, et al. Analysis of 1008 consecutive patients aged 15 to 49 with first-ever ischemic stroke: the Helsinki young stroke registry. Stroke 2009; 40: 1195-1203.

5. Furie KL, Kasner SE, Adams RJ, et al. American Heart Association Stroke Council, Council on Cardiovascular Nursing, Council on Clinical Cardiology, and Interdisciplinary Council on Quality of Care and Outcomes Research. Guidelines for the prevention of stroke in patients with stroke or transient ischemic attack: a guideline for healthcare professionals from the American Heart Association/ American Stroke Association. Stroke 2011; 42: 227-276.

6. Pasierski T, Undas A, Zawilska K, Sosnowski C. Leczenie przeciwzakrzepowe. Wyd. I. Medycyna Praktyczna, Kraków 2007.

7. Gage BF, Waterman AD, Shannon W, et al. Validation of clinical classification schemes for predicting stroke: results from the National Registry of Atrial Fibrillation. JAMA 2001; 285: 2864-2870.

8. Olesen JB, Lip GY, Hansen ML, et al. Validation of risk stratification schemes for predicting stroke and thromboembolism in patients with atrial fibrillation: nationwide cohort study. BMJ 2011; 342: d124.

9. Hart RG, Pearce LA, Aguilar MI. Meta-analysis: antithrombotic therapy to prevent stroke in patients who have nonvalvular atrial fibrillation. Ann Intern Med 2007; 146: 857-867.

10. Camm AJ, Kirchhof P, Lip GY, et al. Guidelines for the management of atrial fibrillation: the Task Force for the Management of Atrial Fibrillation of the European Society of Cardiology (ESC). Europace 2010; 12: 1360-1420.

11. Kukuła K, Kłopotowski M, Konka M, et al. Left atrial appendage occlusion using the PLAATO system in high-risk patients with atrial fibrillation- long term follow-up. Postep Kardiol Inter 2009; 5: 51-57.

12. Holmes D, Reddy V, Turi Z, et al. Percutaneous closure of the left atrial appendage versus warfarin therapy for prevention of stroke in patients with atrial fibrillation: a randomised non-inferiority trial. Lancet 2009; 374: 534-542. 